\title{
Essential Oil of Thujopsis dolobrata Suppresses Atopic Derma- titis-Like Skin Lesions in NC/Nga Mice
}

\author{
Kung-Woo Nam ${ }^{1,6, a}$, Jae Kyu Noh ${ }^{1, a}$, Su Kwan Kim², Sung-Jin Lee ${ }^{3}$, Kyeong Ho Kim4, Ki-bong Oh ${ }^{5}$, \\ Jongheon $\operatorname{Shin}^{1}$ and Woongchon $\operatorname{Mar}^{1, *}$ \\ ${ }^{1}$ Natural Products Research Institute, College of Pharmacy, Seoul National University, Gwanak-gu, Seoul 151-742, \\ ${ }^{2}$ G\&G Co., Ltd, Hwaseong 445-941, \\ ${ }^{3}$ Department of Animal Biotechnology, Kangwon National University, Chuncheon 200-701, \\ ${ }^{4}$ College of Pharmacy, Kangwon National University, Chuncheon 200-701, \\ ${ }^{5}$ School of Agricultural Biotechnology, Seoul National University, Seoul 151-921, \\ ${ }^{6}$ Department of Neuroscience, College of Medicine, Korea University, Seoul 136-701, Republic of Korea
}

\begin{abstract}
We examined the effects of essential oil from Thujopsis dolobrata Sieb. et Zucc. var. hondai Makino (EOTD) (Cupressaceae) on atopic dermatitis (AD)-like skin lesions in NC/Nga mice. Treatment with EOTD twice daily for two weeks ameliorate AD-like skin lesions induced by DNCB (2,4 dinitrochlorobenzene), and clinical scores were reduced to $7.29,7.07$, and 4.5 points in the groups treated with $1.5 \%, 3.0 \%$, and $6.0 \%$ extract $(p<0.01)$ respectively, from the 15.0 score obtained using vehicle. EOTD inhibited the infiltration of mast cells into the AD-like skin lesion in NC/Nga mice $(p<0.01)$ and also reduced serum histamine and IgE levels $(p<0.05)$. Furthermore, it dose-dependently inhibited the release of beta-hexosaminidase from rat basophilic leukemia RBL $2 \mathrm{H} 3$ cells. These results indicate that EOTD reduces AD-like skin lesions by inhibiting the production of lgE and histamine, and, thus, IgE-mediated degranulation.
\end{abstract}

Key Words: Thujopsis dolobrata, Atopic dermatitis, Beta-hexosaminidase, NC/Nga mouse, IgE

\section{INTRODUCTION}

Atopic dermatitis $(A D)$ is a multifactorial allergic inflammatory skin disorder characterized by pruritic and eczematoid skin lesions. $A D$ is commonly present in early infancy and childhood, although it can occur later in life and persist into adulthood (Barker et al., 2007; Brenninkmeijer et al., 2009). It results from interactions between susceptibility genes, the host's environment, skin barrier defects, bacterial and viral skin infections, and immunological factors (Leung and Bieber, 2003). Recent immunological analyses of the pathogenesis of $A D$ have revealed that activated mast cells and an excess in the number of differentiated T-helper 2 (Th2) cells (caused by chemical mediators and cytokines) may play major roles in the development of dermatitis by elevating serum immunoglobulin $E(\operatorname{lgE})$ levels (Leung, 1995). They may trigger the massive infiltration of T cells, eosinophils, mast cells, and macrophages that characterizes AD (Alenius et al., 2002; Milgrom, 2002; Chen et al., 2005).
In the treatment of $A D$, topical glucocorticoids are frequently used to control acute exacerbation (Ference and Last, 2009; Saeki et al., 2009). However, it is well known that prolonged use of high-dose glucocorticoids often cause a variety of adverse effects (Pariser, 2009). In recent years, therefore, alternative approaches have been used to target specific defects in AD (Levin and Maibach, 2002). Results from several studies indicate that $A D$ patients may benefit from herbal Oriental medicine therapy (Qi et al., 2009; Choi et al., 2008). Thujopsis dolobrata Sieb. et Zucc. var. hondai Makino (Cupressaceae) is a plant that grows in Korea and Japan. Thujopsis dolobrata contains a number of neutral terpenoids (Takahashi et al., 2001; Yamaji et al., 2007) and several acidic phenols, tropolones, and lignans (Morita et al., 2003; Morita et al., 2004; Noshita et al., 2009). It has been reported that hinokitiol, the major component of Thujopsis dolobrata, has anti-bactericidal and anti-fungal activity (Morita et al., 2002; Morita et al., 2004). However, whether or how EOTD suppresses AD has www.biomolther.org

Open Access DOI: 10.4062/biomolther.2011.19.1.102

pISSN: 1976-9148 elSSN: 2005-4483

Copyright $\odot 2011$ The Korean Society of Applied Pharmacology
Received Aug 14, 2010 Revised Oct 10, 2010 Accepted Oct 11, 2010

\section{*Corresponding Author}

E-mail:mars@snu.ac.kr

Tel: +82-2-880-2473, Fax: +82-2-880-2474

'These authors contributed equally to this article. 
not been studied.

In this study, we examined the anti-AD effects of EOTD. We used NC/Nga mice for in vivo studies and rat leukemia RBL $2 \mathrm{H} 3$ cells (frequently used as an in vitro model of mast cells) to study the roles of EOTD in IgE-mediated de-granulation.

\section{MATERIALS AND METHODS}

\section{Extraction and analysis of EOTD}

EOTD was extracted from the stem of Thujopsis dolobrata Sieb. et Zucc. var. hondai Makino by boiling according to conventional methods. The EOTD was then weighed to calculate the yield and analyzed by HPLC (RP-18, $5 \mu \mathrm{m}, 250 \times 4.6 \mathrm{~mm})$. A methanol $(\mathrm{MeOH})$ gradient $(100 \% \mathrm{MeOH}(0 \mathrm{~min}), 30 \%$ $\mathrm{MeOH}(30 \mathrm{~min}))$ was applied at a flow rate of $1 \mathrm{ml} / \mathrm{min}$. The EOTD HPLC profile was quantified using its integrated area (Fig. 1).

\section{Animals}

Five-week-old male NC/Nga mice were purchased from Central Lab. Animal, Inc. (Seoul, Republic of Korea) and allowed to acclimatize for 1 week before use. Food and water were provided ad libitum. The EOTD was kindly provided by GNG corporation (Hwaseong-City, Gyeonggi-Do, Republic of Korea). All animal protocols used in this study were approved by the Committee for Animal Experiments of Seoul National University.

\section{Cell culture}

Rat basophilic leukemia (RBL $2 \mathrm{H} 3$ ) cells obtained from Korean Cell Line Bank (Seoul, Korea) were grown in Dulbecco's modified Eagle's medium (Hyclone, Thermo Fisher Scientific Inc., IL, USA) with $10 \%$ heat inactivated fetal bovine serum (GIBCO, Invitrogen, Seoul, Korea) at $37^{\circ} \mathrm{C}$ in $5 \% \mathrm{CO}_{2}$ and complete humidity.

\section{Cell viability assay}

Cell viability was analyzed using an MTT assay. RBL-2H3 cells $\left(5 \times 10^{4}\right.$ cells $(0.2 \mathrm{ml}) /$ well $)$ were plated in 96 -well plates. Samples were treated with various concentrations of EOTD for $24 \mathrm{~h}$. The culture medium was replaced with phenol redfree DMEM containing MTT $(5 \mathrm{mg} / \mathrm{ml})$. Cells were incubated for $4 \mathrm{~h}$ at $37^{\circ} \mathrm{C}$ in $5 \% \mathrm{CO}_{2}$ and complete humidity. After $4 \mathrm{~h}$, the MTT solution was removed and replaced with $250 \mu \mathrm{l}$ of DMSO. Cells were further incubated for $5 \mathrm{~min}$ at room temperature, and the optical densities of the wells at $595 \mathrm{~nm}$ were determined using a plate reader.

\section{Beta-hexosaminidase secretion assay}

RBL-2H3 cells $\left(5 \times 10^{4} /\right.$ well) were sensitized with $300 \mathrm{ng} /$ $\mathrm{ml}$ 2,4-dinitrophenyl (DNP)-specific IgE for $12 \mathrm{~h}$. After three washes in PIPES buffer, cells were exposed to compounds for $24 \mathrm{~h}$ and then challenged with $20 \mathrm{ng} / \mathrm{ml}$ 2,4-dinitrophenylated bovine serum albumin (DNP-BSA) for $30 \mathrm{~min}$. Next, $40 \mu \mathrm{l}$ of supernatant was mixed with an equal volume of substrate solution ( $p$-nitrophenyl- $N$-acetyl- $\beta$-d-glucosaminide $(2 \mathrm{mM})$ in citrate $0.1 \mathrm{M}$ citrate buffer, $\mathrm{pH} 4.5$ ) for $1 \mathrm{~h}$ at $37^{\circ} \mathrm{C}$. Reactions were terminated by adding $50 \mu \mathrm{l}$ of stop solution $(0.5 \mathrm{M}$ $\mathrm{Na}_{2} \mathrm{CO}_{3} / \mathrm{NaHCO}_{3}, \mathrm{pH}$ 10.0). Absorbances were measured at $405 \mathrm{~nm}$ using a microplate reader (Marciniak et al., 2006). Inhibition (\%) of $\beta$-hexosaminidase release by the test samples were calculated by according to the following equation: Inhibition $(\%)=[1-(\mathrm{T}-\mathrm{B} / \mathrm{C}-\mathrm{B})] \times 100$

Control $(\mathrm{C})$ : cells $(+)$, DNP-BSA $(+)$, test sample $(-)$

Test sample $(\mathrm{T})$ : cells $(+)$, DNP-BSA $(+)$, test sample $(+)$

Blank (B): cells $(-)$, DNP-BSA $(+)$, test sample $(+)$

\section{AD induction with DNCB (2, 4-dinitrochlorobenzene)}

Five-week-old NC/Nga mice $(n=35)$ were acclimatized for one week, and each $200 \mu \mathrm{l}$ aliquot of $1 \%$ DNCB in acetone:olive oil $(5: 1)$ was applied to each side of ears and dorsal skin without EOTD. 1\% DNCB was applied every two days for two weeks to induce atopic dermatitis. After two weeks of induction, EOTD $(1.5 \%, 3 \%$, and $6 \%)$ was applied for a further two weeks. The mixture of $1 \%$ betamethasone (BM) and $1 \%$ hydrocortisone (HC) in acetone:olive oil $(5: 1)$ was used as a positive control. Every volume of test sample $(100 \mu \mathrm{l})$ was applied to each mouse.

\section{Histological analysis of DNCB-induced AD}

After two weeks, mice were sacrificed with $\mathrm{CO}_{2}$ gas. Skin tissue was fixed with $10 \%$ neutral formalin solution and then embedded in paraffin by conventional methods. Tissue was cut to a thickness of $5 \mu \mathrm{m}$. Tissue sections were then stained with hematoxylin and eosin (HE) using Mayer's Hematoxylin solution, or with $0.05 \%$ toluidine blue (TB) solution.

\section{Calculation of tissue thicknesses from stained tissue samples}

Epidermal thickness was measured from six serial sections using Image $\mathrm{J}$ freeware obtained from the National Institutes of Health (http://rsb.info.nih.gov/ij/).

\section{Toluidine blue-stained mast cell counts}

Tissue sections were stained with toluidine blue. After staining with toluidine blue working solution for 2-3 min, tissue sections were dehydrated using a series of ethanol solutions (30, $50,70,95$, and $100 \%$ ) and rinsed twice in xylene. Numbers of mast cells in three independent areas $\left(40,000 \mu \mathrm{m}^{2}\right)$ of six serial sections were counted and averaged.

\section{Measurement of serum IgE levels by ELISA}

Whole blood was obtained from mouse tails on day 0 and after 14 days of sample treatment. Sera were stored at $-80^{\circ} \mathrm{C}$ prior to analysis. Total IgE levels were measured using an ELISA kit (Alpha Diagnostic International; \#6370) according to the manufacturer's instructions. $100 \mu \mathrm{l}$ of IgE standard, samples, and controls was added to the wells of a 96-well plate, which was tapped gently to mix the reagents and incubated for 60 min. $100 \mu \mathrm{l}$ of working anti-mouse IgE-HRP conjugate antibody was added to each well, and the plate was incubated for $30 \mathrm{~min}$ before washing. $100 \mu \mathrm{l}$ of enzyme substrate was added to each well. After incubation for $15 \mathrm{~min}$ in the dark, $100 \mu \mathrm{l}$ of stop solutions was added to each well. The plate was then read at $450 \mathrm{~nm}$ using a microplate reader.

\section{Quantification of serum histamine levels by ELISA}

Serum samples were obtained by centrifugation $(1,700 \times \mathrm{g}$, $10 \mathrm{~min}$ ) and stored at $-80^{\circ} \mathrm{C}$ prior to analysis. Total histamine levels were measured using an ELISA kit according to the manufacturer's instructions. $50 \mu$ of histamine standard, samples, and controls was added to the wells of 96 -well plates. 50 $\mu \mathrm{l}$ of ready-to-use enzyme conjugate was added to the wells. 

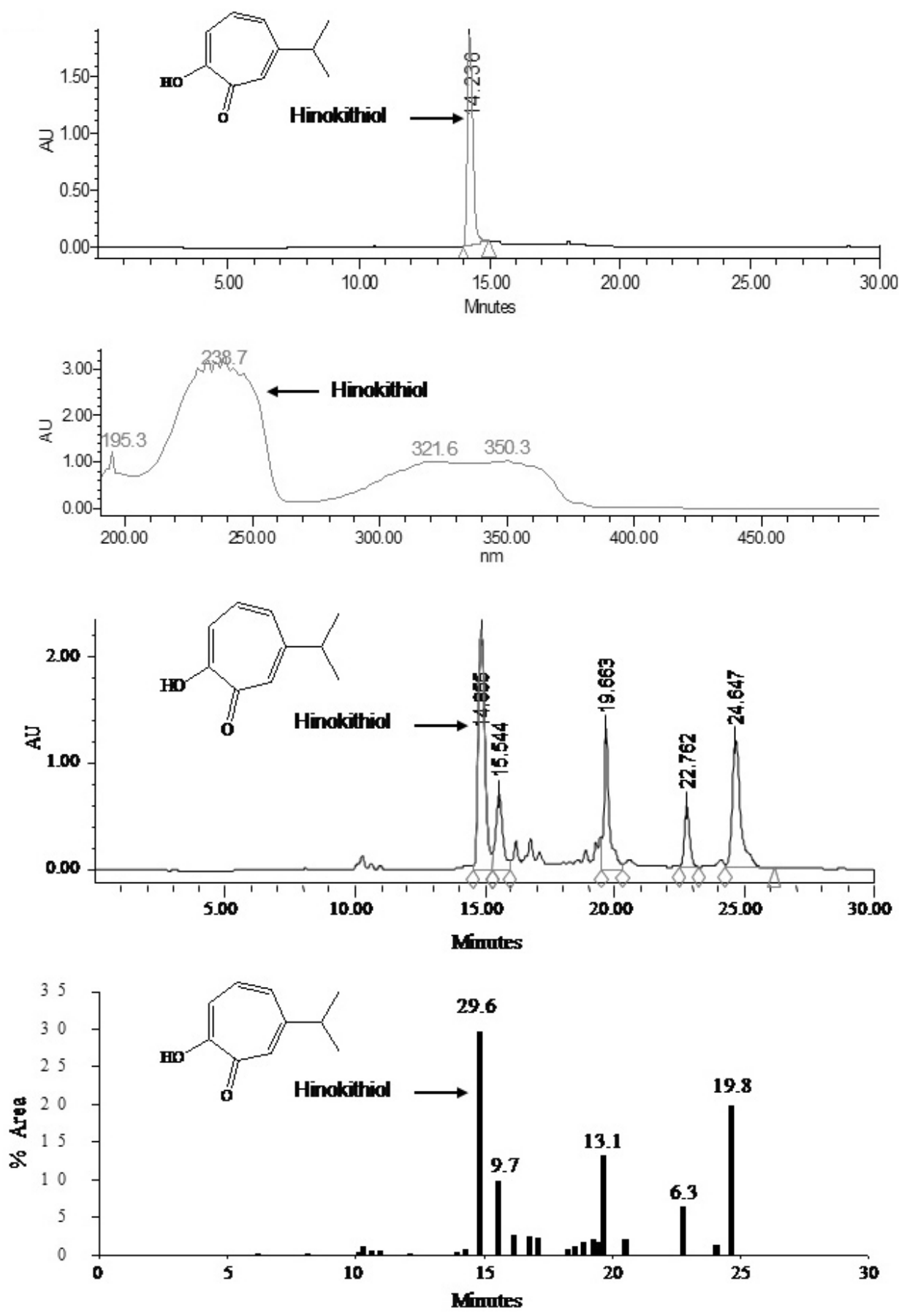

Fig. 1. HPLC profile of EOTD.

After washing, the plates were incubated for $45 \mathrm{~min}$. Following washing, $150 \mu \mathrm{l}$ of substrate was added to each well. After incubation for $30 \mathrm{~min}$, the plates were read at $650 \mathrm{~nm}$ using a microplate reader. Percentage inhibition was calculated as follows: Inhibition \% = [1-(Day14/Day0) $] \times 100$.

\section{Clinical scoring of DNCB induced atopic dermatitis}

Pruritus, edema, erosion, lichenification, and erythema were scored from 0 to 3 ( 0 , no symptom; 1 , mild; 2 , moderate; and 3 , severe). For each treatment group, mean values
( \pm standard deviation) were calculated. Clinical scoring was performed to further investigate the efficacy of EOTD.

\section{Statistical analysis}

Numerical data are expressed as mean \pm standard deviation. Statistically significant differences were identified using the Student's $t$-test. $p<0.05$ was considered to be statistically significant. 


\section{RESULTS}

\section{Clinical scores from EOTD-treated NC/Nga mice}

$A D$ lesions were scored from 0 to 3 on each of five parameters (pruritus, edema, erosion, lichenification, and erythema). In mice treated with 1.5\%, 3\%, and 6\% EOTD, average scores were $7.27 \pm 1.1,7.07 \pm 1.8$ and $4.5 \pm 1.4$, respectively. Compared with animals treated with vehicle (averaged score 15.0 \pm 0.0 ), the experimental group showed significant decreases in clinical AD scores (Table 1).

\section{Effect of EOTD on AD-like skin thickness}

Tissue sections were stained with hematoxylin and eosin, and epidermal thickness was measured (Fig. 2A). Mean epidermal thicknesses (in $\mu \mathrm{m}$ ) in lesional tissue obtained from mice treated with $0 \%, 1.5 \%, 3 \%$, and $6 \%$ EOTD were 186.4 $\pm 16.6,74.7 \pm 24.8,72.8 \pm 23.5$ and $53.9 \pm 19.0$, respectively. Epidermal thickness in the positive control $(\mathrm{BM}+\mathrm{HC})$ group was $53.4 \pm 16.0 \mu \mathrm{m}$. EOTD significantly decreased epidermal thickness $(p<0.01)$.

\section{Histological analysis of mast cell numbers}

Following staining of $A D$ tissue sections with toluidine blue, the number of mast cells was counted. Mast cell counts in mice treated with $0 \%, 1.5 \%, 3 \%$, and $6 \%$ EOTD were $99.7 \pm$ 13.7, $85.6 \pm 7.9,72.9 \pm 6.2$ and $54.8 \pm 6.2$, respectively (Fig. $2 \mathrm{~B})$. The mean count in the positive control $(\mathrm{BM}+\mathrm{HC})$ group was $44.3 \pm 5.1$

Table 1. Clinical DNCB-induced AD scores in NC/Nga mice 14 days after EOTD Treatment. Pruritus, edema, erosion, lichenification, and erythema were scored from 0 to 3 ( 0 , no symptom; 1 , mild; 2 , moderate; and 3 , severe)

\begin{tabular}{cc}
\hline EOTD $(\%)$ & Clinical score \\
\hline Positive control $(\mathrm{BM}+\mathrm{HC})$ & $2.89 \pm 3.5^{\mathrm{a}}$ \\
0 & $15.0 \pm 0.0$ \\
1.5 & $7.29 \pm 1.1^{\mathrm{a}}$ \\
3.0 & $7.07 \pm 1.8^{\mathrm{a}}$ \\
6.0 & $4.5 \pm 1.4^{\mathrm{a}}$ \\
\hline
\end{tabular}

Data are presented as mean \pm SE. Asterisks indicate statistically significant differences between groups. ${ }^{a} p<0.01$.

A

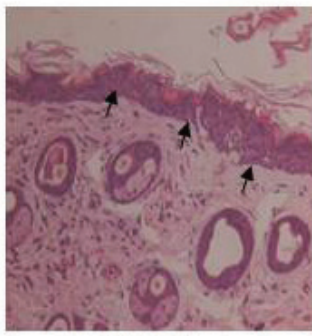

$\mathrm{BM}+\mathrm{HC}$

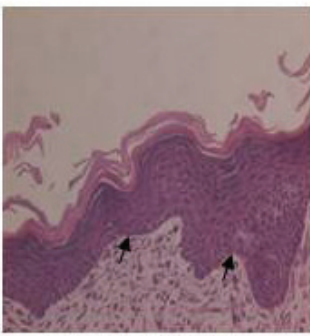

$\operatorname{EOTD}(0 \%)$

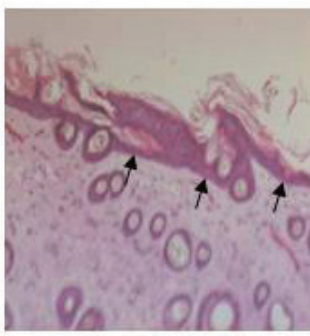

$\operatorname{EOTD}(1.5 \%)$

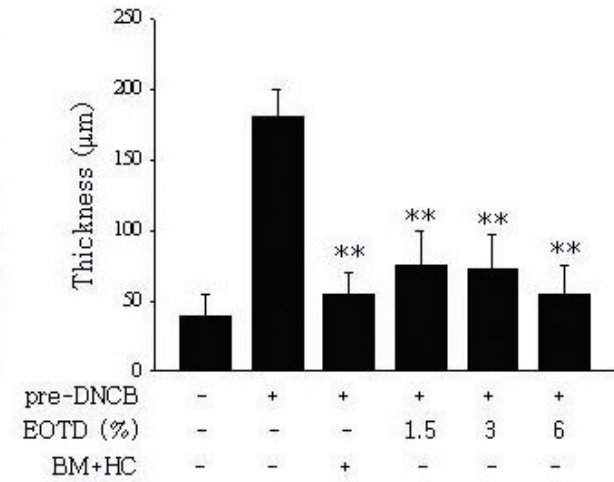

B

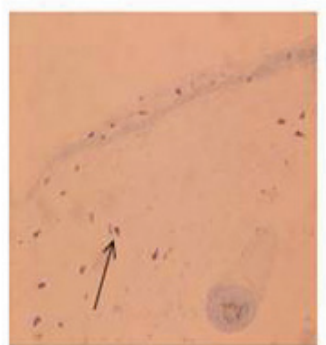

$\mathrm{BM}+\mathrm{HC}$

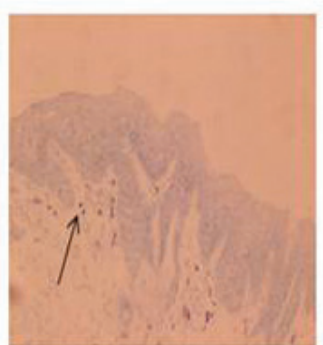

$\operatorname{EOTD}(0 \%)$

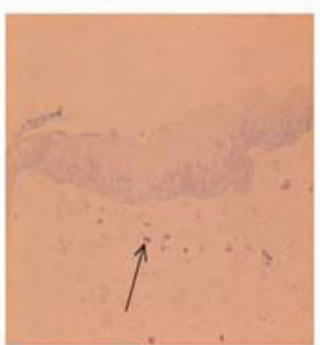

$\operatorname{EOTD}(1.5 \%)$

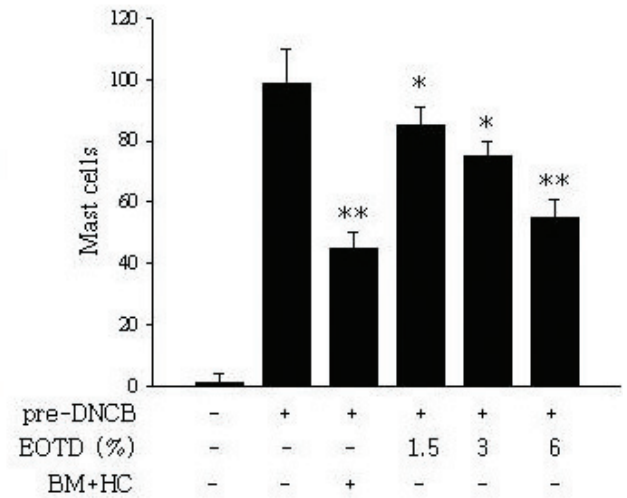

Fig. 2. Effect of EOTD on tissue thickness and mast cell recruitment in NC/Nga mice. (A) In each HE-stained slide, ten areas were randomly selected, and the tissue thickness measured. (B) Skin sections were stained with toluidine blue. Black arrows indicate histamine secretion by mast cells. All images were taken at $200 X$ magnification. Data are presented as mean \pm SD $(n=6)$. Pre-DNCB, pretreated with DNCB for two weeks. ${ }^{*} p<0.05,{ }^{* *} p<0.01$. 


\section{Change in serum levels of lgE and histamine in NC/Nga mice}

After inducing $A D$ through treatment for two weeks with DNCB, serum was isolated from whole blood obtained prior to sample application (day 0) 14 days after sample treatment. Compared to the control group, total IgE levels were reduced by $78.7 \pm 5.3 \%, 75.3 \pm 16.0 \%$ and $67.9 \pm 10.1 \%$ in animals treated $6 \%, 3 \%$, and $1.5 \%$ EOTD, respectively (Fig. 3A). Blood total histamine concentrations were also significantly decreased (by $40.9 \pm 9.5 \%, 42.5 \pm 8.8 \%$ and $49.2 \pm 9.2 \%$ in animals treated with $1.5 \%, 3 \%$, and $6 \%$ EOTD, respectively (Fig. 3B)).

\section{Measurement of $\boldsymbol{\beta}$-hexosaminidase activity}

Rat $\mathrm{RBL} 2 \mathrm{H} 3$ cells were treated with various concentrations $(0.00128-4 \mu \mathrm{g} / \mathrm{ml})$ of EOTD. Levels of degranulation were quantified by measuring $\beta$-hexosaminidase activity. Cells were sensitized with $\lg E$ and activated with DNP-BSA to elicit atopic responses. Treatment with 4, 0.8, 0.16, 0.032, 0.0064, and $0.00128 \mu \mathrm{g} / \mathrm{ml}$ EOTD oil inhibited $\beta$-hexosaminidase re-

A

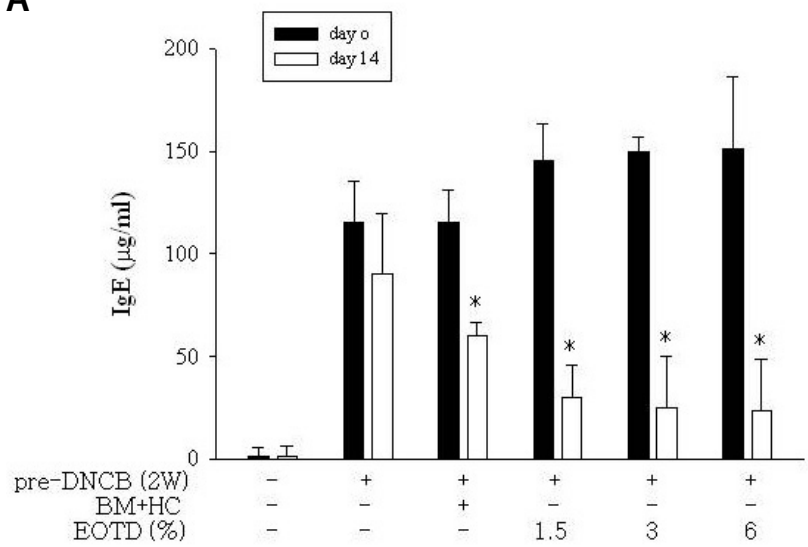

B

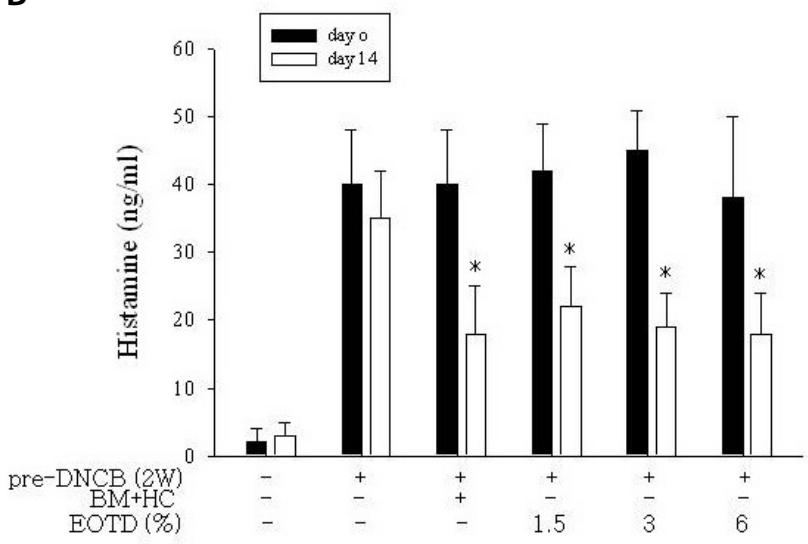

Fig. 3. Effect of EOTD on serum levels of histamine and IgE in $\mathrm{NC} / \mathrm{Nga}$ mice. Day 0 and 14 serum samples from mice treated with $\operatorname{EOTD}(1.5,3$, and $6 \%$ ) (positive control: BM+HC). (A) Serum IgE levels measured by ELISA. (B) Serum histamine levels measured by ELISA. Data are presented as mean $\pm S D(n=6)$. PreDNCB $(2 \mathrm{~W})$, pretreated with DNCB for two weeks. ${ }^{*} p<0.05$. sponses by $45.0 \pm 5.2,43.9 \pm 3.9,38.0 \pm 4.6,17.5 \pm 3.9,11.3$ $\pm 2.7 \%$, and $2.5 \pm 3.2 \%$, respectively (Fig. $4 \mathrm{~A}$ ). Treatment with ketotifen $(4 \mu \mathrm{g} / \mathrm{ml})$ (positive control) reduced degranulation $44.2 \pm 5.1 \%$, which represents a similar levels of inhibition to that achieved with EOTD (Fig. 4A).

\section{Cytotoxic effects of EOTD on RBL 2H3 cells}

$\mathrm{RBL} 2 \mathrm{H} 3$ cells were treated with various concentrations $(0.00128-50 \mu \mathrm{g} / \mathrm{ml})$ of the EOTD oil, and cell viability was determined by means of an MTT assay (Fig. 4B). EOTD reduced cell viability dose-dependently $(p<0.05(50 \mu \mathrm{g} / \mathrm{ml}$ EOTD)). Overall, however, EOTD displayed relatively low cytotoxicity in RBL $2 \mathrm{H} 3$ cells.

A

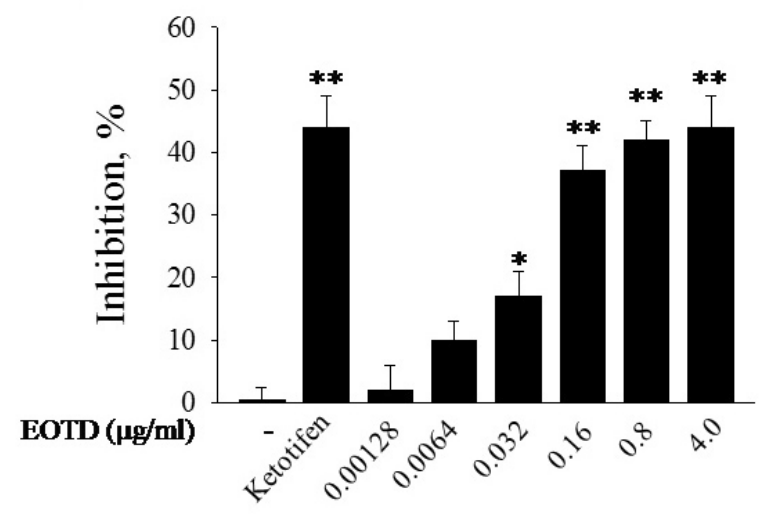

B

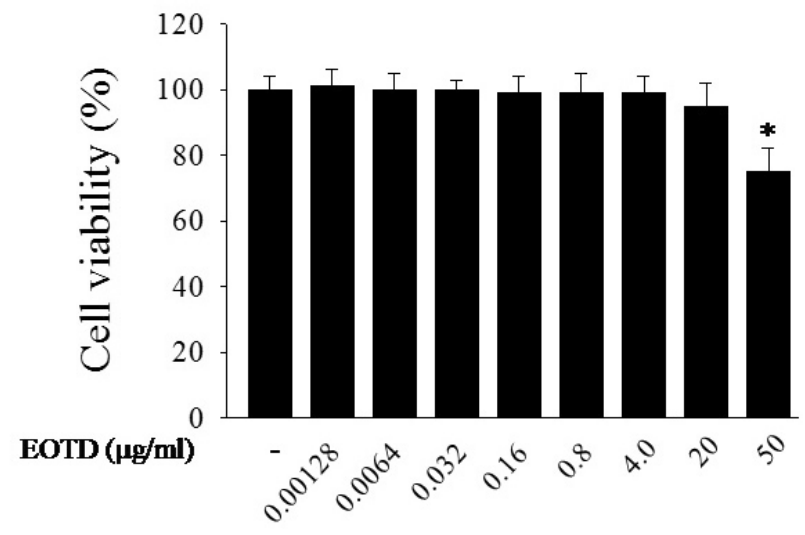

Fig. 4. Effect of EOTD on RBL-2H3 cell viability and $\beta$-hexosamidase release. (A) The effect of EOTD $(0.00128,0.0064$, $0.032,0.16,0.8$, and $4 \mu \mathrm{g} / \mathrm{ml})$ and Ketotifen $(4 \mu \mathrm{g} / \mathrm{ml})$ on $\beta$-hexosaminidase release from RBL-2H3. Data are presented as the mean \pm SD ( $n=3) .{ }^{*} p<0.01,{ }^{* *} p<0.001$ (vs. control). (B) Effect of EOTD $(0.00128,0.0064,0.032,0.16,0.8,4,20$, and $50 \mu \mathrm{g} / \mathrm{ml})$ on $\mathrm{RBL}-2 \mathrm{H} 3$ cell viability. Survival rate data are presented as mean \pm $\mathrm{SD}(\mathrm{n}=3) .{ }^{*} p<0.01$ (vs. control). 


\section{DISCUSSION}

Thujopsis dolobrata is widely distributed in Korea and Japan. From this plant, many terpenoids, acidic phenols, tropolones, and lignans have been isolated. Hinokitiol, the major component of essential oil of Thujopsis dolobrata (Fig. 1), has been reported to possess antimicrobial and antifungal activities (Morita et al., 2002; Morita et al., 2004). However, the inhibitory effects of EOTD in AD-like skin lesion have not been explored. In this study, we investigated weather EOTD ameliorates $A D$-like skin lesions and alters the serum levels of allergic factors such as IgE and histamine in NC/Nga mice. $\mathrm{AD}$-like skin lesions were induced in NC/Nga mice by the repeated application of DNCB for two weeks. Then, mice were treated with or without EOTD for a further two weeks. EOTD effectively lowered skin trauma, as measured by clinical scoring (Table 1). AD is often accompanied by severe itching. This causes scratching, which results in secondary infections by bacteria such as Staphylococcus aureus, and infiltration lesions by mast cells. Hence, it is noteworthy that EOTD suppress mast cell infiltration into the AD-like skin lesions (Fig. 2). It has previously been demonstrated that elevated serum levels of IgE play an important role in the development of AD-like skin lesions in NC/Nga mice (Matsubara et al., 2009). Furthermore, elevated serum IgE levels were correlated with the degranulation of mast cells and eosinophils. Our results showed that administration of EOTD improved AD-like skin lesions and down-regulated serum histamine and IgE levels (Fig. 3). Based on these findings, we concluded that EOTD inhibits the development of DNCB-induced AD-like skin lesions in $\mathrm{NC} /$ Nga mice by reducing serum levels of $\mathrm{IgE}$ and histamine. To exclude the possibility that the development of some chronic AD-like skin lesions in NC/Nga mice occurs independently of plasma IgE (Amon et al., 1995; Fischer et al., 2006; Chen et al., 2008), we further investigated the inhibitory effects of EOTD on mast cells degranulation in an in vitro assay system. The release of $\beta$-hexosaminidase from secretory granules has frequently been used as a measure of mast cell degranulation. As shown in Fig. 4A, EOTD significantly reduced the release of $\beta$-hexosaminidase from RBL-2H3 cells without affecting cell proliferation or viability. The decreased $\beta$-hexosaminidase activity suggests that EOTD inhibits the mast cell degranulation process, which would be expected to affect serum IgE and histamine levels. When activated mast cells release soluble mediators such as histamine and $\operatorname{lgE}$, they typically induce strong Th2 immune responses and, as a result of acute inflammation, increase scratching behavior. A persistent Th2 immune response may lead to chronic inflammation (Elias, 2008). Serum IgE levels were previously shown to be elevated parallel to the development of AD-like skin lesions in NC/Nga mice (Matsumoto et al., 1999; Kawakami et al., 2009). In the present study, EOTD dose-dependently reduced in vitro mast cell degranulation (Fig. 4), lesional epidermal thickness (Fig. 2), and serum IgE and histamine levels (Fig. 3). Serum levels of total serum IgE and hiatamine were measured lower than $25 \mu \mathrm{g} / \mathrm{ml}$ and $30 \mathrm{ng} / \mathrm{ml}$, respectively. While the DNCB (1\%) treatment for two weeks reached high more than $120 \mu \mathrm{g} / \mathrm{ml}$ and $40 \mathrm{ng} / \mathrm{ml}$, respectively. However, EOTD treated groups significantly decreased these total $\lg E$ and histamine levels in the serum.

Hence, it seems that EOTD effectively suppresses the development of atopic dermatitis-like skin lesions by inhibiting of histamine and IgE secretion and the IgE-mediated degranulation, which may in turn reduce infiltration of mast cells into skin lesions (Fig. 2).

In conclusion, we identified anti-allergic effects of EOTD, both in vivo and in vitro. EOTD reduced serum histamine and $\mathrm{IgE}$ levels and mast cell recruitment to skin lesions in NC/Nga mice with $D N C B$-induced $A D$ and also inhibited the release of $\beta$-hexosaminidase from $\mathrm{RBL} 2 \mathrm{H} 3$ cells. Although further detailed studies are necessary to understand the anti-AD mechanisms of EOTD, our results suggest that EOTD may find application as a natural medicine for alleviating AD-like skin lesions.

\section{ACKNOWLEDGMENTS}

This research was supported by the National Research Foundation of Korea (NRF) grant and the Korea government (MEST) (Grant No. 2010-0027734).

\section{REFERENCES}

Alenius, H., Laouini, D., Woodward, A., Mizoguchi, E., Bhan, A. K., Castigli, E., Oettgen, H. C. and Geha, R. S. (2002) Mast cells regulate IFN-gamma expression in the skin and circulating lgE levels in allergen-induced skin inflammation. J. Allergy Clin. Immunol. 109, 106-113.

Amon, U., Dieckmann, D., Nitschke, M., Wehrhahn, C. and Wolff, H. H. (1995) The role of basophilic leukocytes in inflammatory skin diseases. Hautarzt 46, 234-239.

Barker, J. N., Palmer, C. N., Zhao, Y., Liao, H., Hull, P. R., Lee, S. P., Allen, M. H., Meggitt, S. J., Reynolds, N. J., Trembath, R. C. and McLean, W. H. (2007) Null mutations in the filaggrin gene (FLG) determine major susceptibility to early-onset atopic dermatitis that persists into adulthood. J. Invest. Dermatol. 127, 564-567.

Brenninkmeijer, E. E., Legierse, C. M., Sillevis Smitt, J. H., Last, B. F., Grootenhuis, M. A. and Bos, J. D. (2009) The course of life of patients with childhood atopic dermatitis. Pediatr. Dermatol. 26, 14-22.

Chen, L., Lin, S. X., Overbergh, L., Mathieu, C. and Chan, L. S. (2005) The disease progression in the keratin $14 \mathrm{IL}-4$-transgenic mouse model of atopic dermatitis parallels the up-regulation of B cell activation molecules, proliferation and surface and serum IgE. Clin. Exp. Immunol. 142, 21-30.

Chen, L., Overbergh, L., Mathieu, C. and Chan, L. S. (2008) The development of atopic dermatitis is independent of Immunoglobulin $\mathrm{E}$ up-regulation in the K14-IL-4 SKH1 transgenic mouse model. Clin. Exp. Allergy 38, 1367-1380.

Choi, J. J., Park, B., Kim, D. H., Pyo, M. Y., Choi, S., Son, M. and Jin, M. (2008) Blockade of atopic dermatitis-like skin lesions by DA-9102, a natural medicine isolated from Actinidia arguta, in the Mg-deficiency induced dermatitis model of hairless rats. Exp. Biol. Med.(Maywood) 233, 1026-1034.

Elias, P. M. (2008) Barrier repair trumps immunology in the pathogenesis and therapy of atopic dermatitis. Drug Discov. Today Dis. Mech. 5, e33-e38.

Ference, J. D. and Last, A. R. (2009) Choosing topical corticosteroids. Am. Fam. Physician. 79, 135-140.

Fischer, M., Harvima, I. T., Carvalho, R. F., Möller, C., Naukkarinen, A., Enblad, G. and Nilsson, G. (2006) Mast cell CD30 ligand is upregulated in cutaneous inflammation and mediates degranulationindependent chemokine secretion. J. Clin. Invest. 116, 2748-2756 .

Kawakami, T., Ando, T., Kimura, M., Wilson, B. S. and Kawakami, Y. (2009) Mast cells in atopic dermatitis. Curr. Opin. Immunol. 21, 666-678.

Leung, D. Y. (1995) Atopic dermatitis: the skin as a window into the pathogenesis of chronic allergic diseases. J. Allergy Clin. Immunol. 
96, 302-318.

Leung, D. Y. and Bieber, T. (2003) Atopic dermatitis. Lancet 361, 151160

Levin, C. and Maibach, H. (2002) Exploration of "alternative" and "natural" drugs in dermatology. Arch. Dermatol. 138, 207-211.

Marciniak, J., Zalewska, A., Popko, J. and Zwierz, K. (2006) Optimization of an enzymatic method for the determination of lysosomal $\mathrm{N}$ acetyl-beta-D-hexosaminidase and beta-glucuronidase in synovial fluid. Clin. Chem. Lab. Med. 44, 933-937.

Matsubara, T., Aoki, N., Hino, S., Okajima, T., Nadano, D. and Matsuda, T. (2009) Serum and monoclonal immunoglobulin E antibodies from $\mathrm{NC} / \mathrm{Nga}$ mice with severe atopic-like dermatitis recognize an auto-antigen, histone H3. Clin. Exp. Allergy 39, 579-590.

Matsumoto, M., Ra, C., Kawamoto, K., Sato, H., Itakura, A., Sawada, J., Ushio, H., Suto, H., Mitsuishi, K., Hikasa, Y. and Matsuda, H. (1999) IgE hyperproduction through enhanced tyrosine phosphorylation of Janus kinase 3 in NC/Nga mice, a model for human atopic dermatitis. J. Immunol. 162, 1056-1063.

Milgrom, H. (2002) Attainments in atop: special aspects of allergy and IgE. Adv. Pediatr. 49, 273-297.

Morita, Y., Matsumura, E., Okabe, T., Fukui, T., Ohe, T., Ishida, N. and Inamori, Y. (2004) Biological activity of beta-dolabrin, gamma-thujaplicin, and 4-acetyltropolone, hinokitiol-related compounds. Biol. Pharm. Bull. 27, 1666-1669.

Morita, Y., Matsumura, E., Okabe, T., Shibata, M., Sugiura, M., Ohe, T., Tsujibo, H., Ishida, N. and Inamori, Y. (2003) Biological activity of tropolone. Biol. Pharm. Bull. 26, 1487-1490

Morita, Y., Matsumura, E., Tsujibo, H., Yasuda, M., Okabe, T., Sakagami, Y., Kumeda, Y., Ishida, N. and Inamor, Y. (2002) Biological activity of 4-acetyltropolone, the minor component of Thujopsis dolabrata Sleb. et Zucc. hondai MakBiol. Pharm. Bull. 25, 981-985.

Noshita, T., Ishiai, S., Furukido, T. and Funayama, S. (2009) Isolation of (-)-4'-demethyl traxillagenin from Thujopsis dolabrata Sieb. et Zucc. var. hondai Makino. J. Nat. Med. 63, 105-106.

Pariser, D. (2009) Topical corticosteroids and topical calcineurin inhibitors in the treatment of atopic dermatitis: focus on percutaneous absorption. Am. J. Ther. 16, 264-273.

Qi, X. F., Kim, D. H., Yoon, Y. S., Li, J. H., Jin, D., Deung, Y. K. and Lee, K. J. (2009) Effects of Bambusae caulis in Liquamen on the development of atopic dermatitis-like skin lesions in hairless mice. J. Ethnopharmacol. 123, 195-200.

Saeki, H., Furue, M., Furukawa, F., Hide, M., Ohtsuki, M., Katayama, I., Sasaki, R., Suto, H. and Takehara, K. (2009) Guidelines for management of atopic dermatitis. J. Dermatol. 36, 563-577.

Takahashi, K., Nagahama, S., Nakashima, T. and Suenaga, H. (2001) Chemotaxonomy on the leaf constituents of Thujopsis dolabrata Sieb. et Zucc.-Analysis of neutral extracts (diterpene hydrocarbon). Biochem. Syst. Ecol. 29, 839-848.

Yamaji, K., Mori, S., Akiyama, M., Kato, A. and Nakashima, T. (2007) The antifungal compound totarol of Thujopsis dolabrata var. hondai seeds selects for fungi on seedling root surfaces. J. Chem. Ecol. 33, 2254-2265. 